$\xi=-1$

\title{
Mapping and Examining the Subcontracting Process Adopted by Iraqi Quasi-Governmental Construction Companies
}

\author{
Taha S. A. Al-Obaidi ${ }^{*}$, Anthony Higham² \\ ${ }^{I}$ Iraqi ministry of construction and housing, Iraq \\ ${ }^{2}$ University of Salford, UK \\ *Corresponding author E-mail: Tahasame@yahoo.com
}

\begin{abstract}
In today's dynamic business environment, a process view has become a mandatory requirement for any organization striving to excel and stay ahead of the competition. By focusing on improving operational processes, organizations can enhance their overall performance and establish a robust competitive advantage through cost and time reduction alongside increasing the quality of products. With a view of improving the performance of Iraqi Quasi-Governmental Construction Companies (IQGCCs) through instituting the process view. This research, particularly, was designed to map examine the subcontracting process currently in use by IQGCCs. To achieve this aim, three of IQGCCs were selected as case studies to collect the required data. Semi-structured interviews with experts from different management levels of these companies supported by document review and focus groups were the key techniques employed to gather and validate the field data. Four factors, namely: government restrictions, authority distributions, management system and communication system, were identified as the key underpinning causes of the current challenges and barriers to efficiency in the subcontracting process. Accordingly, more studies to improve the efficiency of the current subcontracting process are extremely required.
\end{abstract}

Keywords: business process, Iraqi QGCCs, process mapping, subcontracting process.

\section{Introduction}

Rising the progression of universal exchange alongside the rise of the web and quick data innovation improvement throughout the most recent two decades have all prompted an expansion in worldwide rivalry and differing client needs (Shtub and Karni, 2010; Sivusuo and Takala, 2016). As needs be, item or specialist co-ops have turned out to be not so much secure but rather more helpless against rivalry (Loudon and Carter, 2014). Also, Iraqi Semi Legislative Development Organizations (IQGCCs) have not been safe to the impacts of significant change in their business condition, coming about chiefly from radical changes to political and monetary frameworks in Iraq that occurred after the 2003 clash (Al-Obaidi and Higham, 2017). Actually, the Iraqi new business condition have put these organizations into direct wild rivalry with, more than, 3,500 neighborhood and global private firms. In this manner finishing many years of strength of IQGCCs over most openly financed development contracts. Subsequently, the greater part of IQGCCs have brought about generous money related misfortunes for their failure to both win contracts and produce benefit (IPMO, 2015). In spite of the fact that the Iraqi government endeavors to enhance the execution of these organizations and make them monetarily reasonable, the majority of these endeavors have finished by recapitalizing them instead of tending to their issues (Wing, 2013).

Without a doubt, in the present fierce and profoundly aggressive business condition, fruitful associations are those that can beat their rivals by being better, quicker and less expensive (Loudon and Carter, 2014; Asquith, 2017). Schmidt and Lyle (2010) underline that, with the end goal to be better, quicker and less expen- sive, organizations have one route forward, which is through venture more exertion, time and capital in enhancing their business forms (BPs). Without a doubt, fundamental analysts, including Watchman (1985), Mallet and Champy (1993), McCormack (2007), and all the more as of late vom Brocke and Rosemann (2015) embrace that concentrating on enhancing business process is the most incredible means by which organizations can endure and secure their achievement in the present unique business condition. In addition, a few examinations have exactly exhibited the key benefit of receiving a procedure see inside associations to improve effectiveness and aggressiveness (Ladeira et al., 2016). Consequently, it very well may be contended that a stage change enhancement in IQGCCs' exhibitions can be accomplished by concentrating on enhancing their operational procedures. Be that as it may, an essential for receiving a procedure see is to have an unmistakable comprehension of the current operational process, its difficulties and obstructions to proficiency (Dumas et al., 2013; vom Brocke and Rosemann, 2015). This requires mapping and looking at the "as may be" center business process. By the by, data about the current practices of Iraqi QGCCs are rare, and there are no documentation and maps for their operational procedures or even mandates on how they are performed (Al-Obaidi and Higham, 2017). Appropriately, this exploration intends to connect a piece of this hole in information through mapping and looking at "as seems to be" subcontracting process utilized by these organizations.

The examination features various difficulties innate in the current subcontracting process which primarily relate to four interrelated factors specifically: government limitations, the board framework, specialist dissemination, and correspondence framework. Likewise, there is a requirement for directing more research went for 
tending to the supporting reasons for the distinguished difficulties and along these lines upgrading the general execution of IQGCCs.

\section{Business process (BP) concept and im- portance}

Despite the fact that the accessible writing gives an extensive variety of definitions for a business procedure, in any case, a fundamentally investigating of these definitions shows that the lion's share of them grasp a typical arrangement of principle components. These include: a need (input), an arrangement of even repeatable exercises, a range of existence, assets required to execute the procedure lastly an outcome (yield) that have an incentive for clients (Sledge and Champy, 1993; Palmberg, 2009). These components are additionally exemplified in Al-Obaidi's (2018, p.3) meaning of a business procedure, to be specific as a: "set or gathering of interrelated, rehashed and unmistakably characterized assignments and community oriented exercises masterminded in an even and legitimate arrangement with the end goal to change a quantifiable contribution to an anticipated yield that has an incentive to the clients by utilizing an arrangement of assets and data inside an explicit range of existence". These components all things considered give a business procedure the transformative trademark which is basically founded on a modern rationality proposed by Michael Doorman (1985). Under this rationality, an association ought to be viewed as a chain of exercises that increase the value of a contribution with the point of changing it into a yield that has an incentive to its clients. In this way, exercises don't increase the value of the esteem fasten must be evacuated to lessen the time and cost of the generation procedure.

A procedure, in reality, characterizes the exercises required to achieve a specific objective, close by the manner by which people should act, collaborate and respond to do these exercises in a proficient way (Amaratunga et al., 2005). At the end of the day, forms give rehashed and steady examples of conduct in which individuals, regardless of whether people or gatherings, pursue an organized method for performing errands in the equivalent (or comparable) route on numerous occasions. As needs be, they enable associations to unhesitatingly re-apply effective practices and stay away from those that don't add esteem or can prompt disappointment (Jeong et al., 2004). In this way, when the procedures are normal and very much systematized, representatives can direct their exercises easily, effectively and in concordance with one another, as opposed to, every individual pursues his or her very own way of performing undertakings (Al-ajam, 2008). Besides, the procedure itself ends up straightforward since it simply turns into the standard method for completing business exercises (Jeong et al., 2004; Wu and Ying, 2004).

In a similar vein, Asquith (2017) contends that streamlining the center business process, through evacuating non-included esteem exercises and awful waste, is the way to enhance productivity. In this way, as a reaction to expanding rivalry in the worldwide market, familiarity with business forms has been raised as the most essential administration approach in the new thousand years (Trkman et al., 2015; Glavan and Vuksic, 2017). Today many reference benchmarks, for example, Ability Development Display Coordination (CMMI), global great practice rules, for example, the Undertaking The board Assemblage of Information (PMBOK) and Tasks in Controlled Situations two (Ruler 2) and general rules for quality confirmation, for example, ISO 9001:2008, emphatically advocate that associations should concentrate on dealing with their business forms with the end goal to expand their productivity, business exercises and benefit. By concentrating on the persistent enhancement of operational business forms, associations can upgrade their general execution and set up a vigorous upper hand through cost decrease, quality and effectiveness improvement, and by empowering responsiveness and adjustment to the inside and outside hierarchical changes (McCormack, 2007; vom Brocke and Rosemann, 2015). In like manner, to enhance their execution and gain a superior upper hand required to confront dynamic changes in the commercial center, IQGCCs need to concentrate on enhancing and dealing with their business forms. By the by, an essential advance to enhance an association's operational procedure is to have a reasonable and complete comprehension of its current procedure and the difficulties intrinsic in that procedure. This, as Weske, (2012) and Dumas et al. (2013) declare, can be accomplished through mapping and inspecting of "as-may be" process.

\section{Documentation and mapping "as is" busi- ness processes}

Process mapping is characterized by Marrelli (2005, p.40) as, "the well ordered portrayal of the moves made by specialists as they utilize an explicit arrangement of contributions to create a characterized set of yields". It is a profitable instrument utilized to build up a superior and complete comprehension of the business procedure exercises through displaying these exercises and their sources of info, successions and yields alongside the on-screen characters occupied with performing them in a visual arrangement (Stolzer et al., 2011). It is, along these lines, considered by Malega and Bialkova (2012) as the most essential advance toward building up a procedure see and a procedure enhancement base. Additionally, Macheridis and Nilsson (2006) fight that distinguishing and graphically displaying procedures and the cooperations between them are exceptionally huge, especially, for multi-venture associations, for example, development organizations. Since it encourages ordering, arranging and enhancing venture forms with a perspective of molding the administration of these associations in a powerful way. Development associations may likewise look to report and guide existing procedures with the end goal to upgrade their execution in a dynamic market, as it causes them to concentrate on esteem creation, squander end and enhanced productivity (Lee et al., 2007).

In the course of the most recent three decades, a few procedures have been proposed to encourage mapping forms and organizing the data, for example, Business Process Model and Documentation (BPMN), Information Stream Outline (DFD), and Combination DEFintion Demonstrating (IDEF). Every one of these strategies has its favorable circumstances and weaknesses. In this way, picking among them is on a very basic level subject to the point of demonstrating, framework to be mapped, the modeler's involvement, accessibility of supporting programming, and time and cost requirement (Aguilar-Saven, 2004).

Additionally, Koskela (1995) stresses that procedure mapping strategies used to display a development procedure ought to be expansiveness enough to cover an extensive variety of different procedures and their communication, and profundity enough to grasp extremely essential fundamental builds, for example, exercises succession, inputs, yields, performing artists engaged with the procedure, and so forth. In the interim, they ought to likewise be sufficiently straightforward to be comprehended and utilized and by every one of those engaged with the plan and execution of procedures (Sweet and Schneier, 2013).

The primary motivation behind mapping "as-seems to be" subcontracting procedures of IQGCCs is to build up a superior comprehension of these procedures and catch their key obstructions to proficiency with a perspective of enhancing them. As indicated by Aguilar-Saven (2004), IDEFØ is a standout amongst the most broadly utilized process displaying systems by and by to outwardly showing "as-seems to be" forms with the end goal to look at them and create "to-be" forms. Moreover, in contrast with other displaying strategy, for example, BPMN, IDEF $\varnothing$ is perceived by being very much organized and very basic apparatus to be utilized and comprehended by individuals occupied with structuring and executing forms. Also, this strategy is generally acknowledged and utilized in demonstrating and enhancing the development forms (Koskela, 1995; Cooper et al., 2005; Ekung et al., 2014). In this way, the IDEFØ procedure mapping strategy has been picked as the primary instrument to delineate's "as-may be" subcontracting forms. 
IDEFØ is an utilitarian examination method that is principally planned on a straightforward thought of progressively organized investigation to help decay include. A common chart of IDEFØ incorporates various boxes encompassed by bolts. Each container has a name and speak to a capacity which can be an action, process, activity or change. While, bolts speak to the information sources, yields, control and system of the procedure (Aouad et al., 2013; Oakland, 2014). Figure 1 underneath representations a run of the mill work in the IDEFØ graph.

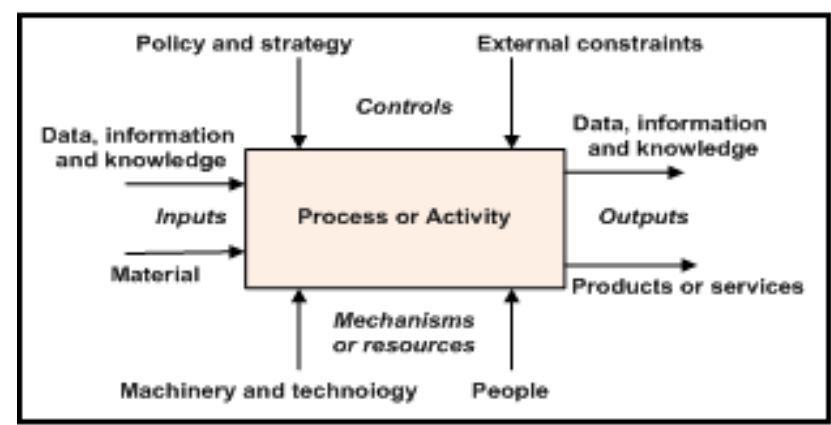

Fig. 1: IDEFØ model language (Oakland, 2014)

\section{Research methodology}

With a perspective of building a thorough picture in regards to the momentum rehearses executed by IQGCCs in subcontracting their works, and as to catch the key hindrances to effectiveness in these practices, three Iraqi QGCCs were tried to be engaged with this examination as contextual investigations. The determination of cases, as declared by Yin (2014), ought to be guided by the replication of rationale. Yin (2014) additionally underlines that a scientist ought to be extremely cautious while picking each case so it either predicts comparable outcomes (a strict replication) or predicts differentiating results however for an anticipatable reason (a hypothetical replication). In light of the analyst's involvement and information created from work for one of the IQGCCs, he can anticipate that the outcomes from concentrate the subcontracting procedures of chose IQGCCs cases will be comparable. This is on the grounds that all IQGCCs are liable to a similar government controls. Likewise, three of these organizations, which have a place with the Service of Development and Lodging, shape the premise of this examination. Table 1 beneath offers some data concerning these organizations.

Table 1: Case studies details

\begin{tabular}{|c|c|c|c|c|}
\hline Name & Specialization & $\begin{array}{c}\text { No. of } \\
\text { employees }\end{array}$ & $\begin{array}{l}\text { Regional } \\
\text { offices }\end{array}$ & Status \\
\hline $\mathrm{CI}$ & Roads \& Bridges & 2042 & 10 & $\begin{array}{c}\text { Money-losing } \\
\text { company }\end{array}$ \\
\hline $\mathrm{C} 2$ & Multidisciplinary & 2218 & 13 & $\begin{array}{c}\text { Money-losing } \\
\text { company }\end{array}$ \\
\hline $\mathrm{C} 3$ & $\begin{array}{c}\text { Building \& } \\
\text { Bridges }\end{array}$ & 1306 & 9 & $\begin{array}{c}\text { Money-losing } \\
\text { company }\end{array}$ \\
\hline
\end{tabular}

In addition, both of Gerring (2008) and Yin (2014) pronounce that embracing a contextual analysis methodology enables analysts to suit numerous information gathering procedures, for example, polls, interviews, documentation audit, and perception. Be that as it may, with the end goal of this examination, semi-organized meetings, documentation audit, and center gathering were utilized as the key devices to gather the required information. Along these lines, by utilizing non-irregular inspecting, six to eight interviewees were chosen from various administration levels inside each contextual investigation. Altogether, the quantity of specialists met was twenty-one. Every one of the respondents were engineers, and each having more than ten years with his/her organization. The meetings were led in Arabic, on eye to eye premise, and in the respondents' workplaces. Each meeting kept going around one hour and every one of the reactions were recorded and after that interpreted inside a few days of the meeting before beginning the underlying mapping. One next to the other with meetings, various pertinent archives and reports were painstakingly inspected. Such archives included yet not constrained to, formal letters, ads and states of offering for new work, the general government controls and enactment in regards to SOEs, official government reports, and so on. Investigating reports was imperative to comprehend the components behind the difficulties in the subcontracting procedure and furthermore to improve the unwavering quality of information acquired from the meetings.

Because of semi-organized meetings and reports audit, a subcontracting procedure delineate produced for each contextual analysis by utilizing IDEF0 strategy. Be that as it may, to build the legitimacy of these maps and guarantee that they precisely mirror the organization current practice, a center gathering included five members was directed inside each contextual investigation. In view of the points of view emerged from the center gathering, various upgrades were made to deliver the last subcontracting procedure delineate each contextual analysis. By and by, the cross-case examination of the considerable number of organizations under investigation uncovered that these organizations embrace nearly the equivalent subcontracting forms. Therefore, close by the constrained space accessible to depict every one of the cases here, one case has been picked for instance speaking to all the three organizations.

\section{Finding from the pilot case study}

\subsection{Company background}

The organization under examination is a general semi administrative development contracting organization, possessed by the Iraqi Service of Development and Lodging. The organization was set up in 1988 with a capital allow of $\$ 14,250,000$, with the point of conveying significant open area supported development ventures, especially, streets and scaffolds. The aggregate number of work force utilized by the organization is 2042 representatives, with $58 \%$ of them are authentic administrative workers on a perpetual contract. As showed in Figure 2, the organization utilized a conventional various leveled structure, in which the work is dispersed over a scope of various offices and sub-offices (segments). Directions and guidelines spill out of the best dimension of the organization, specifically the CEO (Chief), down towards the office executives, area directors and their subordinates at different authoritative dimensions. The organization has likewise founded seven topographical provincial workplaces disseminated around the nation to execute and screen the organization's undertakings. These territorial workplaces are straightforwardly connected to the tasks division, as delineated in Figure 2. Each territorial office is going by a provincial chief and has various utilitarian regions, creation units and undertakings.

In any case, exploring account inspecting reports and execution archives demonstrated that, somewhere in the range of 2007 and 2015 , the organization finished about 90 ventures with an aggregate estimation of up to $\$ 440$ million. However, a report issued by the Iraqi PM's Office in 2015 uncovered that the organization influenced money related misfortunes of up to $\$ 10$ million amid its business activity (IPMO, 2015). It has likewise been noticed that most tasks built by the organization experienced noteworthy postponements, with defer periods regularly surpassing as far as possible permitted in the provisions identified with the installment of postpone punishments. 


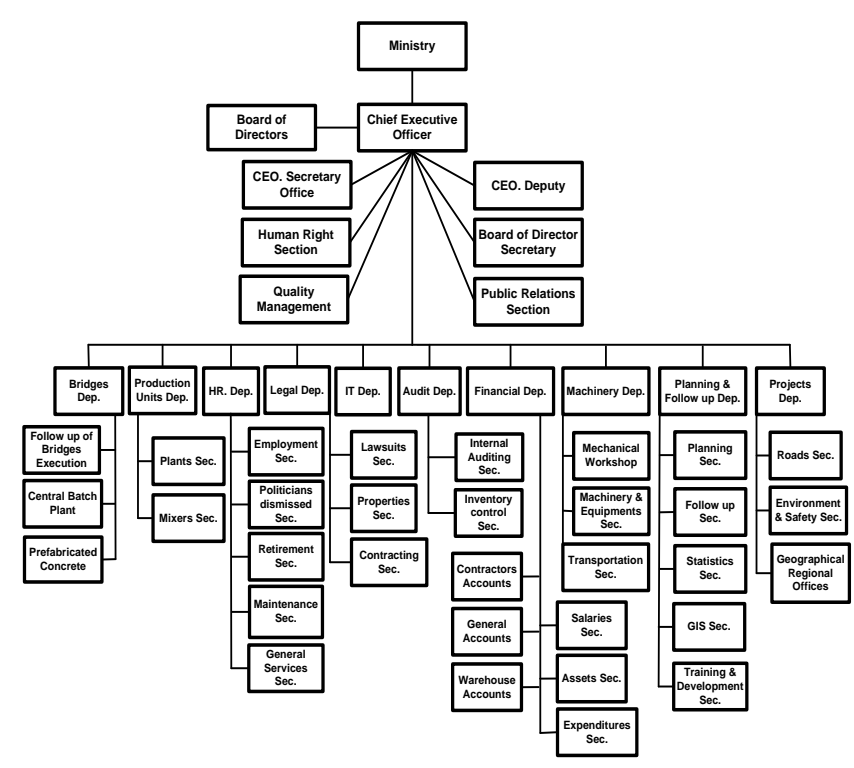

Fig. 2: Organizational structure

\subsection{Company's subcontracting process}

The subjective investigation of the gathered information uncovered that the center business process, embraced by IQGCCs to convey their ventures under a customary acquisition situation, includes four key stages as showed in Figure 3. Subcontracting process, the extent of this exploration, is one of the procedures that are generally utilized by these organizations in acquisition. The subcontracting procedure is generally activated by winning another agreement and the organization requirement for acquiring development materials or works things. While, it closes with the culmination of the development works. All things considered, with the end goal to build up a careful comprehension of the current subcontracting process, it was central to catch the diverse subforms associated with the organization's subcontracting procedure, the partners occupied with executing those procedures, their principle sources of info and yields, lastly to distinguish who is in charge of settling on the key choices all through this procedure. In this manner, utilizing IDEF $\varnothing$ process mapping method, the subcontracting procedure was additionally deteriorated into its subprocesses as portrayed in Figures $4 \mathrm{a}$ and $4 \mathrm{~b}$ individually.

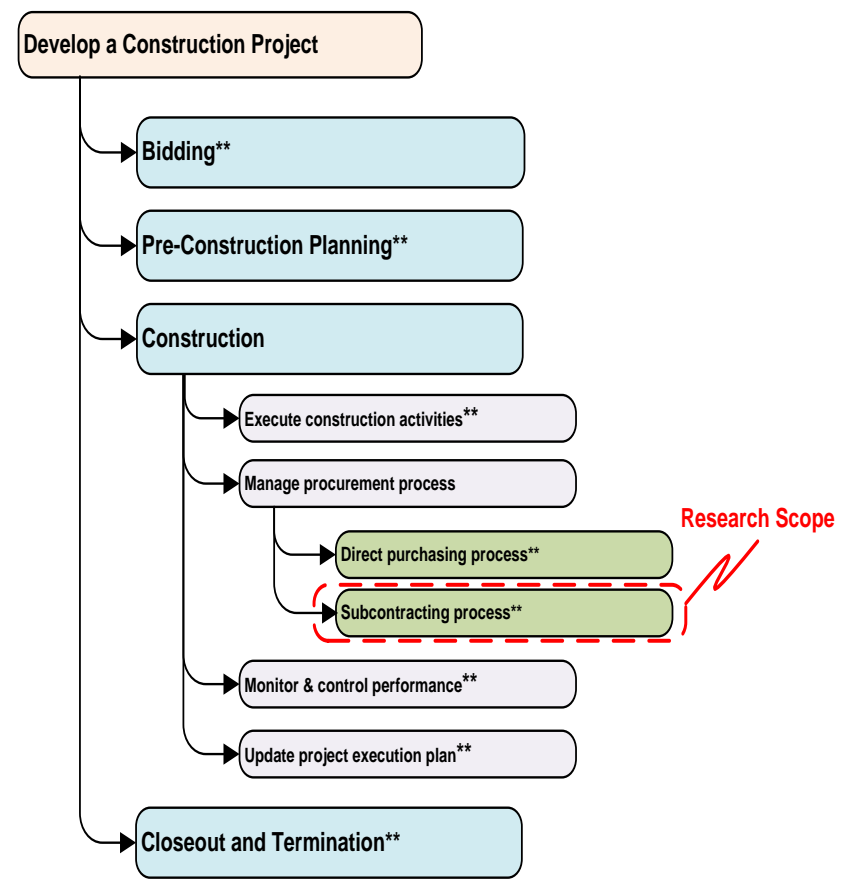

Fig. 3: Activity decomposition diagram expanding the procurement process
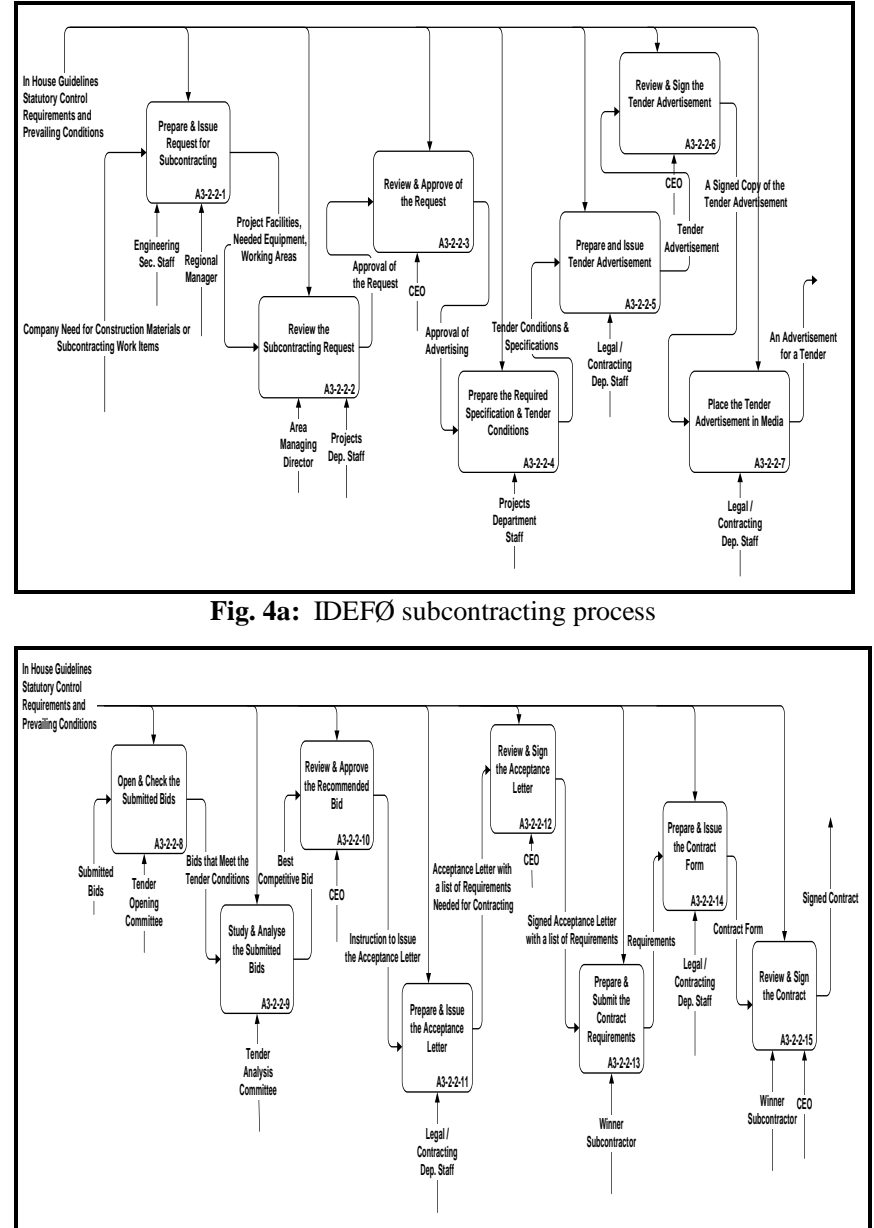

Fig. 4b: IDEFØ subcontracting process

\subsection{Challenges to the subcontracting process}

Having mapped the subcontracting procedure, a basic examination was directed for this procedure with the point of pinpointing its current difficulties and obstructions to productivity. Appropriately, various difficulties intrinsic in the current subcontracting process were caught as exhibited beneath.

\subsubsection{Outdated controls}

The Iraqi Law of State Organizations No.22 of 1997, which is still in power, characterizes IQGCCs as "self-financed, state-claimed monetary units that freely work dependent on the benefit misfortune standard". In any case, exploring the related archives uncovered that the present government directions consider these organizations as open administration government bodies as opposed to as productive associations. As far as subcontracting, the yearly Iraqi Bureaucratic Spending Law urges IQGCCs to consent to the directions stipulated in the Iraqi Controls for Executing Government Contracts of the year 2014. These directions force on IQGCCs to receive the General Tenders Strategy as the main alternative for contracting, except if there are convincing reasons or extraordinary requirements for embracing different strategies. This was additionally affirmed by the depiction given by the interviewees to the subcontracting forms embraced by their organizations, as showed in Figures $4 \mathrm{a}$ and $4 \mathrm{~b}$. Under the General Tenders Technique, associations are not permitted to send off solicitations or direct pre-capability for subcontractors or sellers. Driving various interviewees to portray it as a wasteful technique, since it, right off the bat, gives both the qualified and inadequate temporary workers break even with chances to win, and also keeps organizations from forming and going into long haul associations with certain qualified subcontractors. Along these lines, usually, in the light of the current subcontracting practice, for contracts to be granted to bumbling subcontractors, in this way causing postponements, cost 
increments, and poorer work quality. As the representative provincial supervisor upheld: "On account of the current strict government controls and assessment bodies, the best administration ends up compelled to grant contracts to the proprietors of the most reduced submitted offers, paying little respect to their fitness" (delegate local administrator). This issue was additionally affirmed by one of the organization's provincial chiefs who expressed: "The issue is that an expansive number of contenders, who are typically engaged with the opposition for an agreement, are, as a general rule, not qualified or can satisfy their commitments. Be that as it may, we can't keep them from being included or notwithstanding granting them the agreements, since they give what is required to the delicate accommodation" (territorial administrator).

Also, the putting of delicate commercials (process A3-2-2-7) in three understood government papers as a condition stipulated by the Iraqi Directions for Actualizing Government Contracts is another test in the subcontracting procedure. Because of the way that such papers are generally brimming with promotions, critical deferrals to the publicizing of tenders happen through holding up This hazardous point was accounted for by a senior supervisor who expressed: "Under the Directions for Actualizing Government Contracts, we are compelled to promote in three surely understood government papers. However, the issue is, we don't generally locate an accessible territory for publicizing, what makes us hold up five to ten days until the point that we get our turn" (senior chief). Besides, with the end goal to include the biggest conceivable number of contractual workers in the opposition, the Iraqi Controls for Actualizing Government Contracts stipulates that the time of delicate promotion must not be under 14 days, causing more deferrals. Be that as it may, the major postponements can truly happen when the satisfactory submitted tenders number under three, or when the offered costs are high. In such cases, the organizations are obliged to re-promote the delicate up to two more occasions, as stipulated by the Iraqi Directions for Actualizing Government Contracts.

\subsubsection{Review bodies job}

Notwithstanding the unsafe impact of outdated directions, interviews demonstrated an accord among the different members on the negative pretended by the administrative assessment bodies on the ability of the subcontracting procedure. In this specific situation, an executive of the arranging division contended: "in spite of the fact that organizations under the present controls are not so much bound to acknowledge the most minimal offers, in actuality, they are compelled to do as such just to maintain a strategic distance from inquiries from the staff of Review General Office and Respectability Court" (chief of the arranging office). Shockingly, $90 \%$ of the most reduced bidders, as per territorial administrator from organization two and a venture chief from organization one, are inadequate subcontractors and don't have either the money related or specialized ability to do the works granted according to the agreement. Subsequently, this has adversely thought about the skill of the subcontracting procedure specifically and the general execution of IQGCCs.

\subsubsection{Bureaucratic methods and departmentalization}

Looking into the reports uncovered that acquiring an authorization for a delicate ad more often than not takes seven to ten days. This is for the most part ascribed to the bureaucratic strategies, chain of importance, and the useful framework received by these organizations. As showed in Figure 4A acquiring an authorization for a delicate ad requires the inclusion of four distinct divisions/segments from various administration levels, in particular: the territorial office, the pay/result area, the ventures office, and the Chief. Resounding this contention, a provincial director commented: "do you realize that a standout amongst the most imperative purposes behind deferrals in our undertakings, is identified with the formality methodology and postponement in acquiring the President's endorsement for getting materials and required hardware" (territorial chief). To be sure, mapping the subcontracting procedure uncovered that there are five endorsements required to be acquired from the Chief all through this procedure. Nonetheless, getting such endorsements don't, actually, enhance the procedure, yet they rather confound it and expands its process duration and cost. Driving a senior administrator to contend with discontent: "In view of the strict bureaucratic techniques received, in the most ideal situation, we may require somewhere around two months to finish the way toward subcontracting" (senior chief). In like manner, some of the members accentuated that dispensing with of non-esteem included exercises, and superfluous bureaucratic methods innate in current practices could be accomplished through assigning greater expert to the proper provincial and undertaking the executives. The accompanying statement, conveyed by the executive of activities division, gave an important synopsis of the primary contention: "With the end goal to diminish the formality, we truly need to delegate to the provincial workplaces greater specialist and empower the decentralization of the board. Presently all the official correspondence, obtaining endorsements, subcontracting, installments, and so forth., are completed at the organization's base camp. As I would see it, it is vastly improved that such things are straightforwardly led by our provincial office the executives in order to encourage and quicken the procedures" (chief of the activities office).

In addition, Figures $4 \mathrm{a}$ and $4 \mathrm{~b}$ clearly demonstrate how the procedure has been isolated among a few utilitarian territories (offices). Each practical zone is in charge of undertaking its specific errands and goes it through to the following ones. Bringing about making bounders between the useful zones, which thusly improve subgoals, debilitate intelligibility and joining inside the association, alongside anticipating interior partners shape understanding the center business procedure of their organization.

\subsubsection{Incapable methods for correspondences}

Actualizing a physically determined process through utilizing formal letters as the main adequate way in correspondence is an extra test intrinsic in the current subcontracting process. Prompting increment cost and time required to execute this procedure. This issue was accounted for by a few interviewees, be that as it may, a valuable statement, in this unique circumstance, was made by a venture administrator who expressed: "forcing the utilization of formal letters as the main permitted path in correspondence is dependably an explanation behind stretching the procedure and increment its expense. Do you realize that to stay away from late as can as conceivable in or loss of our endorsement demands, we have doled out a worker to catch up them at the base camp?" (venture supervisor).

\section{Discussion}

According to what has been discussed hereinabove, it is apparent that the most of the barriers to efficiency identified in the current subcontracting processes employed by IQGCCs are attributed to four interrelated causes: Government restrictions; Authority distribution; Management system and; Communication system. These factors are discussed as follows.

Government restrictions: represented by the current government regulations and inspection bodies have played a significant role in promoting the profligate nature of the current subcontracting practice. The qualitative data revealed that IQGCCs under the current government regulations are forced to adopt the General Tenders Method as the only option for subcontracting their works. Although, the main idea of imposing the use of this method is to encourage competition and thus lower prices. However, the interviews uncovered that such belief is outmoded and can really harm the companies. Since within the current practice of General Tendering, companies are not allowed to conduct pre-qualification for subcontractors and suppliers. But rather they are forced by the governmental inspection bodies to award contracts to the lowest 
prices bidders, who the majority of them, as reported by interviewees, are unqualified. Which in turn negatively affects the performance of these companies through increasing the time and cost of construction and reducing the quality of deliverables, along with preventing these companies from building robust and longterm partnerships with good qualified vendors and subcontractors to enhance their supply chain and thereby their performances. Align with this, Cooke and Williams (2009) emphasize that smaller and more integrated supply chains can significantly enhance the construction industry's demands for improving productivity, completion on time and budget within higher standards. Accordingly, many of the top construction companies have recognized that in order to better meet the industry needs, they need to change their culture by getting into long-term partnerships with fewer and better suppliers and subcontractors (Zairi, 2011; Holden, 2016) Moreover, the procedures followed in the General Tendering Methods are themselves complex, lengthy and effort-consuming. Data showed that awarding any contract may require two months at the least. However, by entering into long-term relationships with fewer and qualified subcontractors and vendors, value can be added to the supply chain through avoiding many time-, cost- and effort- consuming formalities. The time and effort saved can then be employed to negotiate long-term price framework and discuss method statement, construction programs, delivery schedules and quality issues (Cooke \& Williams, 2009; Harris \& McCaffer, 2013).

Authority: mapping and examining the subcontracting process of IQGCCs showed that these companies are managed through a very centralized control system. Under this system, top management holds the ultimate authority and almost all decisions must be reviewed and ratified by the CEO before an action can be taken Thus, a CEO's approval is usually required at several points throughout the process before allowing it to proceed further. For example, data revealed that there are five approvals must be obtained from the CEO across the subcontracting process. Considering the adoption of a hierarchical structure, the process is forced to repeatedly go up and down across the different management layers, taking in that a zigzag path rather than straight horizontal. Resulting in creating workflow bottleneck and task duplication at several points of the process, which lead to considerable increasing in the process time and cost. Therefore, both Banner and Gagne (1995) and Graetz (2009) consider a centralised bureaucratic system as an outdated system unable to meet the requirements of the nowadays business environment. Since, while waiting for a decision to go up through a few administration layers to be surveyed and confirmed, and after that goes down toward the most reduced layer for the usage, the organization can be past the point where it is possible to adapt to the significant changes happen in its business condition. Interestingly, examines demonstrate that designating and pushing expert for basic leadership down to center and lower the executives levels can give a few advantages to associations. As indicated by Olson et al. (2005), it permits the development of various thoughts and perspectives from various gatherings of work and engages chiefs to react quickly to issues that are near them, as they possibly have more data with respect to their work issues than others (Acemoglu et al. 2007). Both Ryan and Deci (2006) and Yang and Choi (2009) observationally discovered that the appointment of power decidedly added to expanding the inspiration, fulfillment and execution of representatives. Additionally, Pink (2011) refers to an investigation led by Cornell College, which secured 320 private companies of which half granted their laborers self-rule, while the other half relied upon a best down hierarchal methodology. The investigation found that the organizations that utilized self-rule developed at multiple times the rate of the concentrated and control-arranged organizations. Holt et al. (2000) additionally recommend that development organizations which disregard the procedure of workers' strengthening may lose their market position, and eventually, their upper hands. This lines up with the point of view of IQGCCs specialists, who maintained that the assignment of power to the center and lower the executives layers is a key driver for streamlining the subcontracting procedure and along these lines enhancing the execution.

Management: subjective information additionally demonstrated that IQGCCs are overseen through a conventional useful administration framework commanded by pecking order, incorporated control, and organization. Under this administration framework, organizations have been isolated along the side into a few useful territories (offices) and vertically into various administration layers. In like manner, a procedure instead of on a level plane goes over these useful territories, it has been partitioned into various exercises conveyed to a few secluded useful zones, where each utilitarian territory is in charge of playing out its own exercises and send it to the following one. Bringing about an absence of lucidness and combination among the different divisions, which thus prompted make a rich domain for deferrals, increment in the business cost, and decrease of value. This finding has additionally upheld the contention made by Sungau et al. (2013), who propose that in spite of the fact that a conventional useful administration framework can upgrade nearby advancement, nonetheless, it as a rule prompts damage to by and large execution. This is on the grounds that each useful zone would be more focused without anyone else destinations and methods for playing out its organizations, with little thoughtfulness regarding the generally speaking authoritative objectives and targets. In like manner, the distinctive objectives, interests and foundations of the general population inside these useful territories as a rule make hindrances between them, which lead to issues in correspondence and wasteful coordination in handovers between capacities (Shtub and Karni, 2010). Bringing about a contention between these utilitarian zones, more postponement, and expanded expense.

Additionally, a basic driver to enhance an association's execution, as distinguished by Skrinjar et al. (2010), is that each person in the association ought to have a reasonable perspective of the company's regular procedures and an exact comprehension of their jobs in the procedures and how that partners with building the master plan. This can be accomplished by embracing process considering and in this way observing the association as a gathering of incorporated procedures instead of various utilitarian regions. Process considering, as declared by McCormack (2007), permits and even empowers, workers to look past their own undertakings and the limits of their specializations to consider any inadequacies and bottlenecks in the entire business process. It offers inside partners from various ability, a typical dialect and a strong stage to collaborate and associate with one another under a similar objective and goals (Tang et al., 2013). It outwardly demonstrates to them the job of every partner in the business procedure and how they cooperate to create a last item or administration (Bernstein and Singh, 2006).

Communication framework: depending basically on a manual paper-driven framework as the main acknowledged route in authority interchanges was likewise recognized as a key factor for postponement, expanded expense and inefficacy of the current subcontracting process. Be that as it may, tending to this issue can be through embracing data innovation as an elective means for the current one whether in correspondence or information store. As indicated by Alshawi (2007) building up a focal database, that interfaces all the organization's units and extends and is open to the partners, can significantly quicken the procedure, diminish its expenses, and enhance the nature of correspondence through giving brisk, dependable, and energetic correspondence courses. It additionally gives a compelling apparatus to putting away and keeping up information in a sorted out and effective way. Reports and other pertinent archives created all through the execution of the procedures can be put away on IT frameworks to be inspected and displayed in various perspectives (Al-Atawi, 2005). Such information would be pivotal for illustration exercises and teaching associations on their encounters, regardless of whether they are effective or unsuccessful, and applying that exercises figured out how to future tasks (Khol, 2016). 


\section{Conclusion}

In the light of today's turbulent business environment, much robust evidence, from both the theoretical and empirical studies, demonstrate the vital role and strategic value of employing process view in managing organizations. So as a step to institutionalize a process view within IQGCCs, and thereby improving their performance, this research has provided a graphical representation to the subcontracting practice currently in use by these companies. This exercise uncovered a number of challenges inherent in the subcontracting process leading to delay, increase cost, and reduce the quality of deliverables. Inflexibility of selecting the most appropriate procurement system, bureaucratic and red tape procedures, workflow bottlenecks, duplication of tasks, lack of coherence and integration along with the ineffective means of communications are among the key challenges facing the current IQGCCs' subcontracting processes. The research also revealed that most of these challenges are attributed to four interrelated factors, namely 1) government restrictions; 2) authority distribution; 3) management system; and 4) communication system. The government restrictions represented by the outdated government regulations, and inspection bodies have led to increasing the inflexibility, rigidity, and red-tape whether in the selection of the procurement type or within the current subcontracting process itself. Restriction almost all the approval authority to the top management also has contributed to create workflow bottlenecks and duplication of tasks. Moreover, adopting the functional, hierarchical and centralised management system to operate the companies has further led to create a working environment characterized by bureaucracy, administrative routine, and inflexibility. Using a manually driven system based on formal paper letters as the only accepted means of communication has additionally resulted in lengthening, and complicating the process. Accordingly, in order to improve the subcontracting process of IQGCCs and further enhance their performance, more research on how to address the current challenges identified in the subcontracting process are indeed required.

\section{References}

[1] Acemoglu, D., Aghion, P., Lelarge, C., Van Reenen, J. \& Zilibotti, F. (2007). Technology, information, and the decentralization of the firm. Quarterly Journal of Economics, 122(4), 1759-1799.

[2] Aguilar-Saven, R. S. (2004). Business process modelling: Review and framework. International Journal of production economics, 90(2), 129-149.

[3] Al-Ajam, M. (2008). Integrating collaborative extranets with project integrate databases to improve the construction tender stage. (Unpublished PhD Thesis), University of Salford, Salford.

[4] Al-Atawi, S. (2005). An ICT framework to improve the tendering process in the governmental construction sector in the Kingdom of Saudi Arabia. (Unpublished PhD thesis). University of Salford, Salford

[5] Al-Obaidi, T. (2018). A transformational organisational for improving Iraqi quasi-governmental construction companies' performance. (Unpublished PhD Thesis), University of Salford, Salford.

[6] Al-Obaidi, T., \& Higham, A. (2017). Examining and mapping the bidding process of Iraqi quasi-governmental construction companies. Paper presented at the 13th International Postgraduate Research Conference, Salford, Uk.

[7] Alshawi, M. (2007). Rethinking IT in construction and engineering: Organisational readiness. London: Taylor \& Francis.

[8] Amaratunga, D., Haigh, R., \& Baldry, D. (2005). Structured process improvements in facilities management organisations: best practice case studies in the retail sector. In 11th Joint CIB International Symposium - Combining Forces - Advancing Facilities Management and Construction through Innovation. Retrieved from http://usir.salford.ac.uk/9922/.

[9] Aouad, G., Wu, S., Lee, A., \& Onyenobi, T. (2013). Computer aided design guide for architecture, engineering and construction. London: Spon Press.

[10] Asquith, P. (2017). Better, faster and cheaper?. Retrieved 31 May 2017 from https://www.realysgroup.com/2017/04/10/better-fasterand-cheape
[11] Banner, D., \& Gagné, T. (1995). Designing effective organizations: Traditional and transformational views. California: Sage.

[12] Bernstein, B., \& Singh, P. (2006). An integrated innovation process model based on practices of Australian biotechnology firms. Technovation, 26(5), 561-572.

[13] Brocke, J., \& Rosemann, M. (2015). Handbook on business process management 1: Introduction, methods, and information systems. (2nd. Ed.). New York: Springer Science.

[14] Cooke, B., \& Williams, P. (2009). Construction planning, programming and control. (3rd Ed.). UK: Wiley-Blackwell.

[15] Cooper, R., Aouad, G., Lee, A., Wu, S., Fleming, A., \& Kagioglou, A. (2005). Process management in design and construction. Oxford: Wiley-Blackwell.

[16] Dumas, M., La Rosa, M., Mendling, J., \& Reijers, H. A (2013). Fundamentals of business process management. New York: Springer Heidelberg.

[17] Ekung, S., Adeniran, L., \& Adu, E. (2014). Appraisal of process mapping in heavy engineering projects: a case of Nigeria East-West Coastal Highway. International Letters of Natural Sciences, 20, 17 27.

[18] Gerring, J. (2008). Case study research: principles and practices. Cambridge: Cambridge University Press.

[19] Glavan, L. M., \& Vuksic, V. B. (2017). Examining the impact of business process orientation on organizational performance: the case of Croatia. Croatian Operational Research Review CORR, 8(1), 13.

[20] Graetz, F. \& Smith A. (2009). Duality theory and organizing forms in change management. Journal of Change Management, 9(1), 9-25.

[21] Hammer, M., \& Champy, J. (1993). Reengineering the corporation: A manifesto for business revolution. New York: Harper Business.

[22] Harris, F., McCaffer, R., \& Edum-Fotwe, F. (2013). Modern construction management. (7th Ed.). UK: Wiley-Blakwell.

[23] Holden, R. K. (2016). Negotiating with backbone: Eight sales strategies to defend your price and value. New Jersey: Pearson Education.

[24] Holt, G., Love, P., \& Jawahar Nesan, L. (2000). Employee empowerment in construction: an implementation model for process improvement. Team Performance Management: An International Journal, 6(3/4), 47-51.

[25] IPMO (2015). Reconstruction of Iraqi state-owned enterprises: the reality... vision toward reforming. Iraqi Prime Minister Office.

[26] Jeong, K. S., Siriwardena, M. L., Amaratunga, R. D. G., Haigh, R. P., \& Kagioglou, M. (2004). Structured process improvement for construction enterprises (SPICE) level 3: establishing a management infrastructure to facilitate process improvement at an organisational level. $\quad$ Retrived from http://usir.salford.ac.uk/9965/1/280_Jeong_KSStructured_Process_ Improvement.pdf.

[27] Kohl, K. (2016). Becoming a Sustainable Organization: A Project and Portfolio Management Approach. Boca Raton: Taylor \& Francis Gro.

[28] Koskela, L. (1995). On foundations of construction process modelling. In CIB Workshop on Computers and Information in Construction. Stanford, California.

[29] Ladeira, M. B., Resende, P. T. V. D., Oliveira, M. P. V. D., McCormack, K., Sousa, P. R. D., \& Ferreira, R. L. (2016). The effects of analytical and business process orientation approaches on the performance of small and medium industrial and service enterprises in Brazil. Gestão \& Produção, 23(3), 486-502.

[30] Lee, D., Song, Y. \& Choi, Y. (2007). Continuous improvement plan of business process in construction company. Proc. Conf. of IGLC15, Michigan, USA. Retrieved from http://wenku.baidu.com/view/155bbc21bcd126fff7050bd2.html?fro $\mathrm{m}=$ related.

[31] Loudon, D., \& Carter, T. (2014). Many thin companies: The change in customer dealings and managers since September 11, 2001. London: Routledge.

[32] Macheridis, N., \& Nilsson, C. (2006). Management of multiprojects in a process oriented organization. Working Paper Series from Lund University, Institute of Economic Research. Retrieved from

http://www.kunskapspartner.se/wpcontent/uploads/2012/02/Mgmtof-multi projects_2006.pdf.

[33] Malega, P., \& Bialkova, D. (2012). Process management and process maps-trend in management of advanced businesses-review article. International Journal of Advances in Management and Economics, 1(5), 105-109.

[34] Marrelli, A. (2005). The performance technologist's toolbox: process mapping. Performance Improvement, 44(5), 40-44. 
[35] McCormack, K. (2007). Introduction to the theory of business process orientation. In K. McCormack (Ed.), Business process maturity. Theory and application (pp. 1-18). South Carolina: Booksurge Publishing.

[36] Oakland, J. (2014). Total quality management and operational excellence: text with cases. (4th Ed.). New York: Routledge.

[37] Olson, E. M., Slater, S. F., \& Hult, G. T. M. (2005). The performance implications of fit among business strategy, marketing organization structure, and strategic behavior. Journal of marketing, 69(3), 49-65

[38] Palmberg, K. (2009). Exploring process management: Are there any widespread models and definitions? The TQM Journal, 21(2), 203-215.

[39] Pink, D. (2011). Drive: The surprising truth about what motivates us. (3rd Ed.). London: Penguin Publishing Group.

[40] Porter, E. (1985). Competitive advantage: Creating and sustaining superior performance. New York: The Free Press.

[41] Ryan, R. M., \& Deci, E. L. (2006). Self-regulation and the problem of human autonomy: does psychology need choice, self-determination, and will?. Journal of personality, 74(6), 15571586.

[42] Schmidt, J., \& Lyle, D. (2010). Lean integration: An integration factory approach to business agility. London: Pearson Education.

[43] Shtub, A., \& Karni, R. (2010). ERP: the dynamics of supply chain and process management. (2nd. Ed.). New York: Springer Science \& Business Media.

[44] Sivusuo, J., \& Takala, J. (2016). Management changes in MRO business through product lifecycle. Management and Production Engineering Review, 7(3), 87-93.

[45] Skrinjar, R., Bosilj Vuksic, V., \& Indihar-Stemberger, M. (2010). Adoption of business process orientation practices: Slovenian and Croatian survey. Business System Research, 1(1-2), 5-19.

[46] Stolzer, A., Halford, C., \& Goglia, J. (2011). Implement safety management systems in aviation. England: Ashgate Publishing Limited.

[47] Sungau, J., Ndunguru, P., \& Kimeme,J. (2013). Business process re-engineering: the technique to improve delivering speed of service industry in Tanzania. Independent Journal of Management \& production (IJM\&P), 4(1), 208-227.

[48] Sweet, J., \& Schneier, M. M. (2013). Legal aspects of architecture, engineering and the construction process. (9th Ed.). Stamford: Cengage Learning.

[49] Tang, J., Pee, L., \& Iijima, J., (2013). Investigating the effects of business process orientation on organizational innovation performance. Information \& Management, 50 (2013) 650-660.

[50] Trkman, P., Mertens, W., Viaene, S., \& Gemmel, P. (2015). From business process management to customer process management. Business process management journal, 21(2), 250-266.

[51] Vom Brocke, J., \& Rosemann, M. (2015). Handbook on business process management 1: Introduction, Methods, and Information Systems. (2nd Ed.). London: Springer.

[52] Weske, M. (2012). Business process management: Concepts, languages, architectures. (2nd Ed.). New York: Springer.

[53] Wing, J. (2013). Musings on Iraq: Problems reforming Iraq's state owned enterprises. Retrieved 7 May 2018 from http://musingsoniraq.blogspot.co.uk/2013/03/problems- reformingiraqs-state-owned.html.

[54] Wu, H., \& Ying, J. (2004). How can process help CSCW?. In Computer Supported Cooperative Work in Design, 2004. Proceedings. The 8th International Conference on (Vol. 2, pp. 302-306). IEEE.

[55] Yang, S. B., \& Ok Choi, S. (2009). Employee empowerment and team performance: Autonomy, responsibility, information, and creativity. Team Performance Management: An International Journal, 15(5/6), 289-301.

[56] Yin, R. (2014). Case study research: Design and methods. (5th Ed.). London: Sage Publication.

[57] Zairi, M. (2011). Benchmarking for best practice: Continuous learning through sustainable innovation. New York: Routledge. 